\title{
ВПЛИВ СИМУЛЯЦІЙНОГО НАВЧАННЯ НА КОМПЕТЕНТНІСТЬ ЛІКАРІВ АКУШЕРІВ-ГІНЕКОЛОГІВ У ВЕДЕННІ КОНСЕРВАТИВНИХ ПОЛОГІВ ПРИ ТАЗОВОМУ ПЕРЕДЛЕЖАННІ ПЛОДА
}

\author{
O. M. Kalanzhova \\ Odesa National Medical University \\ EFFECT OF SIMULATION TRAINING ON COMPETENCE \\ OF OBSTETRICIAN-GYNECOLOGISTS IN DURING THE ASSISTANCE \\ OF CONSERVATIVE CHILDBIRTH \\ AT THE PELVIC PRESENTATION OF THE FETUS
}

\begin{abstract}
Мета роботи - встановити вплив симуляційного навчання на підвищення професійного рівня лікарів акушерів-гінекологів під час надання допомоги дитині у пологах у тазовому передлежанні, за алгоритмом, відповідним діючим протоколам Міністерства охорони здоров’я України, в умовах, максимально наближених до реальних.

Основна частина. Для досягнення визначеної мети на кафедрі акушерства та гінекології № 1 із циклом післядипломної освіти Одеського національного медичного університету оброблено 150 анонімно заповнених курсантами анкет-тестів до початку та після завершення тренінг-заняття з теми “Ведення консервативних пологів при ТПП” у складі курсу тематичного удосконалення “Актуальні питання в акушерстві та перинатології”. Цикл розрахований на лікарів акушерів-гінекологів пологового відділення II або III рівнів надання акушерської допомоги, зі стажем роботи від 5 років. Тривалість циклу становила 75 годин. 32016 року до курсу тематичного удосконалення “Актуальні питання в акушерстві та перинатології” були залучені симуляційні технології з метою оволодіння та відпрацювання практичних навичок лікарями акушерами-гінекологами з відповідних тем, у тому числі й з ведення консервативних пологів при ТПП. Кожна група курсантів на тренінг-заняттях складалася з 6 лікарів. Тренінгове заняття з ведення консервативних пологів при ТПП складалося з 4-х частин. Перша частина присвячувалася брифінгу. Друга частина полягала у вивченні біомеханізму пологів при ТПП та оцінки інтранатального стану плода. Третя частина була основною, що містила безпосередньо тренінг-імітацію надання акушерської допомоги дитині при народженні у тазовому передлежанні в умовах, максимально наближених до реальних. I четверта частина - дебрифінг із використанням відеозаписів, де кожний учасник мав змогу побачити свої помилки та переваги, що необхідно в собі підтримувати і надалі розвивати. Ефективність тренінг-заняття з консервативного ведення пологів при ТПП оцінювалася шляхом аналізу анкет-тестів курсантів до початку та після завершення навчання.

Висновки. Аналіз анкет-тестів, що заповнювалися курсантами, дозволив отримати інформацію відносно їх суб’єктивної оцінки свого вихідного професійного рівня та впливу виду навчання на його зміни. Середній вік лікарів становив $(33,2 \pm 4,6)$ року (від 27 до 62 років). Всі вони були працівниками пологових відділень лікувальних закладів II та III рівнів надання акушерської допомоги м. Одеси та Одеської області. Ведення консервативних пологів при ТПП у своїй лікарській діяльності відмічали як рідкісну практику. В якості провідних перешкод спеціалісти вказували на: особливості організаційних моментів у своїх лікувальних закладах, недостатність теоретичної підготовки, невпевненість у власних практичних здібностях, юридичну незахищеність та відсутність мотивації.
\end{abstract}

Ключові слова: симуляційні технології; практичні навички; пологи в тазовому передлежанні плода.

The aim of the work - to establish the influence of simulation training on the increase of the professional level of obstetriciangynecologist doctors during assistance in childbirth in the pelvic presentation, according to the algorithm, in accordance with the effective protocols of the Ministry of Health of Ukraine, in conditions that are as close as possible to the real ones.

The main body. To achieve a specific goal, at the Department of Obstetrics and Gynecology No.1 with the cycle of postgraduate education of the Odesa National Medical University, 150 anonymous questionnaire-filled cadets were processed before and after the completion of the training session on the theme of Conductive Conservative Births at the CCI in the course of the thematic improvement of Topical Issues in Obstetrics and Perinatology. The cycle is designed for doctors obstetricians-gynecologists in the maternity ward II or III levels of obstetric care, with a work experience of 5 years. The cycle lasted 75 hours. From 2016, simulation technologies were introduced to the thematic improvement of Actual Problems in Obstetrics and Perinatology with the aim of mastering and practicing practical skills of doctors obstetricians-gynecologists on relevant topics, including those related to conservative childbirth at CCI. Each group of cadets in the training session consisted of 6 doctors. Training sessions for conducting conservative births at CCI consisted of

(c) О. М. Каланжова 
4 parts. The first part was dedicated to the briefing. The second part was to study the biomechanism of childbirth at the CCI and assess the intranatal condition of the fetus. The third part was the main one, which included a training simulation of the provision of obstetric care to a child at birth in a pelvic presentation in conditions that are as close as possible to the real. And the fourth part is video rebranding, where each participant was able to see his mistakes and benefits that he needs to sustain and further develop. The effectiveness of the training-lessons on conservative management of childbirth at CCIs was assessed by analyzing questionnaire tests for cadets before and after the completion of training.

Conclusions. The analysis of questionnaire tests, which were blocked by cadets, allowed to receive information regarding their subjective assessment of their initial professional level and the influence of the type of training on its changes. The average age of doctors was (33.2 \pm 4.6$)$ years (from 27 to 62 years). All of them were employees of the maternity wards of medical institutions of II and III levels of provision of obstetric care in Odesa and Odesa oblast. Keeping conservative births at CCI in their medical activities was marked as a rare practice. As the leading obstacles, the specialists pointed out: the peculiarities of organizational moments in their medical institutions, lack of theoretical training, insecurity in their own practical abilities, legal insecurity and lack of motivation.

Key words: simulation technologies; practical skills; labor with pelvic presentation of the fetus.

Вступ. Багаторічна консервативна методика виключно теоретичної підготовки практикуючих лікарів на етапі післядипломної освіти сьогодні перестала відповідати провідним світовим медичним вимогам [4]. А сучасна система охорони здоров'я потребує комплексного підходу у підготовці професійних клініцистів, який приділятиме достатньо уваги не лише наданню оновленої, науково достовірної інформації, але й практичним навичкам спеціалістів. Так, досвід багатьох країн демонструє успішне вирішення зазначеної проблеми із залученням у навчальний процес симуляційних технологій $[1,3,7,8]$. Такі інноваційні перетворення медичної освіти дозволяють посилити практичний аспект підготовки висококваліфікованих професіоналів, не порушуючи юридичні, етичні та деонтологічні елементи лікарської діяльності [2, 5, 6]. Враховуючи те, що найбільш гостро “ціна помилки” стоїть в акушерській практиці, а оволодіння практичними навичками при наданні консервативної допомоги у пологах при тазовому передлежанні плода (ТПП) $є$ одним із найскладніших аспектів, обгрунтованою та зрозумілою буде ретельна увага щодо вивчення впливу залучення симуляційного навчання на формування стійких вмінь, підтримку та підвищення високопрофесійних навичок саме в лікарів акушерів-гінекологів.

Мета роботи - встановити вплив симуляційного навчання на підвищення професійного рівня лікарів акушерів-гінекологів під час надання допомоги дитині у пологах у тазовому передлежанні, за алгоритмом, відповідним діючим протоколам Міністерства охорони здоров’я України, в умовах, максимально наближених до реальних.

Основна частина. Для досягнення визначеної мети на кафедрі акушерства та гінекології № 1 із циклом післядипломної освіти Одеського національного медичного університету оброблено 150 анонімно заповнених курсантами анкет-тестів до початку та після завершення тренінг-заняття 3 теми “Ведення консервативних пологів при ТПП” у складі курсу тематичного удосконалення “Актуальні питання в акушерстві та перинатології”. Цикл розрахований на лікарів акушерів-гінекологів пологового відділення II або III рівнів надання акушерської допомоги, зі стажем роботи від 5 років. Тривалість циклу становила 75 годин. 32016 року до курсу тематичного удосконалення “Актуальні питання в акушерстві та перинатології” були залучені симуляційні технології з метою оволодіння та відпрацювання практичних навичок лікарями акушерами-гінекологами з відповідних тем, у тому числі й з ведення консервативних пологів при ТПП. Кожна група курсантів на тренінг-заняттях складалася 36 лікарів. Тренінгове заняття 3 ведення консервативних пологів при ТПП складалося з 4-х частин. Перша частина присвячувалася брифінгу. Друга частина полягала у вивченні біомеханізму пологів при ТПП та оцінки інтранатального стану плода. Третя частина була основною, що містила безпосередньо тренінг-імітацію надання акушерської допомоги дитині при народженні у тазовому передлежанні в умовах, максимально наближених до реальних. I, нарешті, четверта частина - дебрифінг із використанням відеозаписів, де кожний учасник мав змогу побачити свої помилки та переваги, що необхідно в собі підтримувати і надалі розвивати. Ефективність тренінг-заняття з консервативного ведення пологів при ТПП оцінювалася шляхом аналізу анкет-тестів курсантів до початку та після завершення навчання. Усі тренінги циклу проводилися виключно викладачами кафедри, які мають сертифікат тренера. Відпрацювання практичних навичок надання акушерської допомоги при вагінальних пологах у ТПП проводилося на тренажері пологів 3B Birthing Simulator PRO. Анкети курсантів були розподілені на 2 групи : I - основна група (ОГ) (n=75), анкети курсантів, які прослухали виключно теоретичну частину надання допомоги при консервативних пологах у ТПП; II - контрольна 
група (КГ) (n=75), анкети курсантів, які пройшли комплексну, із залученням симуляційного навчання, підготовку у наданні допомоги при консервативних пологах у ТПП.

Статистичну обробку отриманих результатів проводили за допомогою програмного забезпечення Microsoft Office Excel 2016 із використанням статистичних методів варіаційного, непараметричного аналізу. Статистично значущими вважались значення $\mathrm{p}<0,05$.

Аналіз анкет-тестів, що заповнювалися курсантами, дозволив отримати інформацію відносно їх суб’ єктивної оцінки свого вихідного професійного рівня та впливу виду навчання на його зміни. Середній вік лікарів становив $(33,2 \pm 4,6)$ року (від 27 до 62 років). Всі вони були працівниками пологових відділень лікувальних закладів II та III рівнів надання акушерської допомоги м. Одеси та Одеської області. Ведення консервативних пологів при ТПП у своїй лікарській діяльності відмічали як рідкісну практику. В якості провідних перешкод спеціалісти вказували на: особливості організаційних моментів у своїх лікувальних закладах, недостатність теоретичної підготовки, невпевненість у власних практичних здібностях, юридичну незахищеність та відсутність мотивації.
Так, вивчення вихідної суб’єктивної оцінки курсантів до навчання за 10-бальною системою в переліку параметрів у тест-анкетах демонструвало відсутність статистичної різниці в обох групах по всіх пунктах (табл. 1).

Тоді як вивчення суб’єктивної оцінки спеціалістів в динаміці щодо впливу запропонованих способів навчання на зміни їхнього професійного рівня демонструвало за тест-анкетами статистично достовірну ефективність тренінг-занять із консервативного ведення пологів при ТПП (табл. 2).

Так, після завершення навчання з теми “Ведення консервативних пологів при ТПП” за традиційним теоретичним способом надання оновленої, науково достовірної інформації курсанти І групи не відмітили суттєвих суб’ єктивних змін у своїх професійних навичках. Встановлено, що досить невелика кількість спеціалістів відмітила незначну сприятливу зміну єдиного параметра у тест-анкеті - правильний відбір пацієнток, що покращило його значення після навчання $3(3,1 \pm 0,3)$ бала до $(4,1 \pm 0,2)$ бала (p>0,05). При цьому параметри психоемоційного (власний рівень психологічної толерантності, власна мотивація) та практичного (точність рухів, акуратність маніпуляцій та обережне ставлення до плода) аспектів надання консервативної допомоги

Таблиця 1. Оцінка курсантами власних навичок у проведенні консервативних пологів при ТПП до проведення навчання (бали)

\begin{tabular}{|c|c|c|}
\hline Параметр, що оцінюється & $\begin{array}{c}\text { I група } \\
(n=75)\end{array}$ & $\begin{array}{c}\text { II група } \\
(n=75)\end{array}$ \\
\hline Правильний відбір пацієнток & $3,1 \pm 0,3$ & $2,8 \pm 0,5$ \\
\hline Власний рівень психологічної толерантності & $2,2 \pm 0,8$ & $2,5 \pm 0,2$ \\
\hline Точність рухів & $1,7 \pm 1,1$ & $1,3 \pm 0,8$ \\
\hline Акуратність маніпуляцій та обережне ставлення до плода & $3,3 \pm 0,4$ & $2,9 \pm 0,8$ \\
\hline Власна мотивація & $0,7 \pm 0,1$ & $1,1 \pm 0,3$ \\
\hline
\end{tabular}

Примітка. * - p<0,05 різниця між групами дослідження.

Таблиця 2. Оцінка курсантами власних навичок у проведенні консервативних пологів при ТПП після завершення навчання (бали)

\begin{tabular}{|l|c|c|}
\hline \multicolumn{1}{|c|}{ Параметр, що оцінюється } & $\begin{array}{c}\text { I група } \\
(\mathrm{n}=75)\end{array}$ & $\begin{array}{c}\text { II група } \\
(\mathrm{n}=75)\end{array}$ \\
\hline Правильний відбір пацієнток & $4,1 \pm 0,2$ & $9,1 \pm 0,6^{*} * *$ \\
\hline Власний рівень психологічної толерантності & $2,2 \pm 0,8$ & $5,9 \pm 0,4^{*} * *$ \\
\hline Точність рухів & $1,7 \pm 1,1$ & $8,8 \pm 0,7^{*} * *$ \\
\hline Акуратність маніпуляцій та обережне ставлення до плода & $3,3 \pm 0,4$ & $8,4 \pm 1,1^{*} * *$ \\
\hline Власна мотивація & $0,7 \pm 0,1$ & $7,1 \pm 1,6^{*} * *$ \\
\hline
\end{tabular}

Примітки:

1. * $-\mathrm{p}<0,05$ порівняно $з$ оцінкою до навчання.

2. ** $-\mathrm{p}<0,05$ порівняно з оцінкою у І групі. 
при пологах у ТПП залишилися, за оцінками лікарів, незмінними.

Поряд із цим аналіз тест-анкет II групи свідчив про статистично сприятливий вплив навчання за схемою тренінг-занять на практичні навички лікарів акушерів-гінекологів. Найсприятливіших змін зазнавав показник параметра - правильний відбір пацієнток $((9,1 \pm 0,6)$ бала). Він статистично сприятливо змінювався відносно як свого вихідного рівня - $(2,8 \pm 0,5)$ бала, так і рівня відповідного параметра після навчання в I групі - $(4,1 \pm 0,2)$ бала $(\mathrm{p}<0,05)$. Також курсанти II групи демонстрували підвищення суб’ єктивної оцінки власного рівня надання практичної допомоги при консервативних пологах у ТПП: точність рухів $(3(1,3 \pm 0,8)$

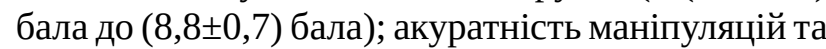
обережне ставлення до плода (з $(2,9 \pm 0,8)$ бала до $(8,4 \pm 1,1)$ бала) $(\mathrm{p}<0,05)$. При цьому рівні маніпулятивних навичок у II групі статистично сприятливо змінювалися також й відносно відповідних у I групі після навчання: точність рухів (I - $(1,7 \pm 1,1)$ бала, II - $(8,8 \pm 0,7)$ бала); акуратність маніпуляцій та обережне ставлення до плода (I - $(3,3 \pm 0,4)$ бала, II - $(8,4 \pm 1,1)$ бала) (p<0,05). На відміну від I групи, тренінг заняття із використанням симуляційного навчання також ефективно впливали на зміни низького вихідного рівня власної мотивації спеціалістів II групи у бік спроби консервативного вирішення питання пологів у ТПП $(3(1,1 \pm 0,3)$ бала до $(7,1 \pm 1,6)$ бала) $(\mathrm{p}<0,05)$. Достовірно сприятливих змін після навчання в II групі зазнавав й показник власного рівня психологічної толерантності лікарів (з $(2,5 \pm 0,2)$ бала до $(5,9 \pm 0,4)$ бала) $(p<0,05)$. Втім, з усіх параметрів тест-анкети зазначений показник змінювався найменше, що обумовлювалося

\section{Список літератури}

1. Ефективність симуляційних методів навчання / В. В. Артьоменко, Д. А. Новіков, О. С. Єгоренко, С. С. Семенченко // Управління закладом охорони здоров’я. - 2015. - № 6. - С. 70-76.

2. Розвиток практично-орієнтованого та симуляційного навчання в Тернопільському державному медичному університеті імені І. Я. Горбачевського / М. М. Корда, А. Г. Шульгай, А. А. Гудима, С. Й. Запорожан // Медична освіта. - 2016. - № 2. - С. 54-57.

3. Симуляційне навчання в медицині: міжнародний та вітчизняний досвід / В.В.Артьоменко, С. С. Семченко, О. С. Єгоренко, Д. А. Новіков // Одеський медичний журнал. - 2015. - № 6. - С. 67-74.

4. Корда М. М. Шляхи імплементації Закону України “Про вищу освіту” в Тернопільському державному медичному університеті / М. М. Корда, А. Г. Шульгай, I. М. Кліщ // Медична освіта. - 2015. - № 2. - С. 34-39. оцінками певної кількісті курсантів, чиї показники рівня психологічної толерантності залишилася незмінними наприкінці заняття.

Перспективи досліджень в обраному напрямку полягають у можливості винаходу найефективнішого способу підготовки високопрофесійних спеціалістів різних медичних направлень за допомогою симуляційного навчання у системі сучасного реформування охорони здоров’я.

Висновки. 1. Про низькоефективний вплив ізольовано-теоретичного навчання на рівень професіоналізму сучасних лікарів акушерів-гінекологів свідчать незмінні показники параметрів тест-анкет I групи після навчання (p>0,05). Зазначене вимагає не лише перегляду структури багаторічної практики підготовки та вдосконалення лікарів сьогодення, але й впровадження у неї різноманітних елементів симуляційного навчання з огляду на наукові дані.

2. Залучення симуляційних технологій до підготовки та підвищення кваліфікації сучасних лікарів акушерів-гінекологів дає можливість ефективно вплинути на професійний рівень спеціалістів шляхом: тренування толерантності до великих психоемоційних навантажень, відпрацювання взаємодії у команді та надання права на помилку, вміння прогнозування її виникнення й своєчасного попередження без жодних ризиків для життя і здоров'я пацієнтки та її дитини.

3. На шляху зменшення кількості несприятливих наслідків в акушерстві та гінекології реалістичність, різноманітність та індивідуальність симуляторів-тренажерів сьогодення пропонує як можливість підготовки молодих лікарів із формуванням у них вихідного високого рівня вмінь, так і стійку підтримку професійних навичок вже досвідчених спеціалістів.

5. Ayres-de-Campos D. Sustaining simulation training programmes - experience from maternity care / D. Ayresde-Campos, S. Deering, D. Siassakos // BJOG. - 2011. Vol. 118 (Suppl. 3). - P. 22-26.

6. Impact of intrapartum simulation based training on clinical knowledge, technical and nontechnical skills. PhD Thesis by Ana Reynolds (Saraiva), University of Porto, 2012 (http://repositorio) aberto.up.pt/handle/10216/75206.

7. Kamran Khan. Simulation in medical education / Kamran Khan, Tim Pattison, Morgan Sherwood // Medical Teacher. - 2011. - No. 1. - P. 1-1530.

8. Does simulation-based medical education with deliberate practice yield better results than traditional clinical education? A meta-analytic comparative review of the evidence / W. C. McGaghie, B. S. Issenberg, R. E. Cohen [et al.] // Acad. Med. - 2011. - Vol. 86. P. 706-711. 


\section{References}

1. Artomenko, V.V., Novikov, D.A., Yehorenko, O.S., \& Semenchenko, S.S. (2015). Efektyvnist symuliatsiinykh metodiv navchannia [Efficiency of simulation teaching methods]. Upravlinnia Zakladom okhorony zdorovia Management of the Health Care Establishment, 6, 70-76 [in Ukrainian].

2. Korda, M.M., Shulhai, A.H., Hudyma, A.A., Zaporozhan, S.Y. (2016). Rozvytok praktychno-oriientovanoho ta symuliatsiinoho navchannia v Ternopilskomu derzhavnomu medychnomu universyteti imeni I. Ya. Horbachevskoho [Development of practical-oriented and simulation training at the I. Ya. Horbachevsky Ternopil State Medical University]. Medychna osvita - Medical Education, 2, 5457 [in Ukrainian].

3. Artomenko, V.V., Semchenko, S.S., \& Yehorenko, O.S. (2015). Symuliatsiine navchannia v medytsyni: mizhnarodnyi ta vitchyznianyi dosvid [Simulation study in medicine: international and domestic experience]. Odeskyi medychnyi zhurnal - Odesa Medical Journal, 6, 67-74 [in Ukrainian].

Електронна адреса для листування: leda_darina@ukr.net
4. Korda, M.M., Shulhai, A.H., \& Klishch, I.M. (2015). Shliakhy implementatsii Zakonu Ukrainy "Pro vyshchu osvitu” v Ternopilskomu derzhavnomu medychnomu universyteti [The ways of implementation of law of Ukraine "On higher education” in Ternopil State Medical University]. Medychna osvita - Medical Education, 2, 34-39 [in Ukrainian].

5. Ayres-de-Campos, D., Deering, S., \& Siassakos, D. (2011). Sustaining simulation training programmes experience from maternity care. BJOG, 118 (3), 22-26.

6. Impact of intrapartum simulation based training on clinical knowledge, technical and nontechnical skills. PhD Thesis by Ana Reynolds (Saraiva), University of Porto, 2012 (http://repositorio) aberto.up.pt/handle/10216/75206.

7. Khan, K., Pattison, T., \& Sherwood, M. (2011). Simulation in medical education. Medical Teacher, 1, 1-1530.

8. McGaghie, W.C., Issenberg, S.B., \& Cohen, E.R. (2011). Does simulation-based medical education with deliberate practice yield better results than traditional clinical education? A meta-analytic comparative review of the evidence. Acad. Med., 86, 706-711.

Отримано 02.05.18 